\title{
Od historycznej do etnicznej Polski. Od wizji Oskara Żebrowskiego do projektu Czesława Jankowskiego
}

\section{Piotr Eberhardt}

https://orcid.org/0000-0002-4601-1130

Instytut Geografii i Przestrzennego Zagospodarowania im. Stanisława Leszczyckiego

Polskiej Akademii Nauk

Zarys treści: W artykule przedstawiono i porównano ze sobą dwa projekty granic politycznych potencjalnego państwa polskiego. Pierwszy z nich to wizja autorstwa Oskara Żebrowskiego powstała w Paryżu w 1847 r., drugi zaś zaprojektował Czesław Jankowski w 1914 r. Oba przedstawiały oryginalne koncepcje hipotetycznych przyszłych granic Polski, zostały zilustrowane mapami, opisane i zinterpretowane. Wizja Żebrowskiego nawiązywała do zaszłości historycznych, Jankowskiego zaś oparta była o kryteria etniczne, wyznaczył on przyszłe granice Polski, biorąc pod uwagę migracje, umiejscowienie ludności i zasięg języka polskiego. Oba projekty różniły się znacznie położeniem i kształtem granic, co wynikało z odmiennego podejścia autorów. Analiza obu map i porównanie z rzeczywistymi powojennymi granicami Polski umożliwia weryfikację dokładności i realizmu każdej z koncepcji.

Słowa kluczowe: granice Polski, Oskar Żebrowski, Czesław Jankowski

Działacze polityczni oraz uczeni zainteresowani geografią traktują mapę jako dogodny argument wizualny przy prezentowaniu swych poglądów i wizji geopolitycznych. Zastępuje ona opis i długie wywody werbalne, które nigdy nie gwarantują ścisłości i precyzji w wymiarze czasu i przestrzeni. Ujęcie kartograficzne jest przydatne przy pokazywaniu zasięgów i rozległości terytorialnej, zmienności i przebiegu granic, kierunków ekspansji oraz usytuowania geograficznego i strategicznego państw. Wykreślenie aktualnych oraz kreowanie nowych pożądanych rozgraniczeń politycznych daje przesłanki do różnorodnych
Abstract: The article refreshes two territorial concepts referring to Polish political borders. The first one was created in 1847 by Oskar Żebrowski, and the second one in 1914 by Czesław Jankowski. Both concepts presenting the original ideas of the hypothetical future borders of Poland were illustrated with the maps that were described and interpreted. Oskar Żebrowski demarcated the borderlines based on the remains of the former Republic of Poland. Czesław Jankowski presented the ethnical approach and established future Polish borders reflecting the migrations and location of the Polish population and language. Both projects differed significantly in terms of size and shape due to the authors' different approaches. The analysis of both maps and the comparison to the actual post wars borders of Poland enables the verification of how accurate and realistic each of them was.

Keywords: Poland's borders, Oskar Żebrowski, Czesław Jankowski

wniosków poświęconych przyszłej roli poszczególnych jednostek politycznych i relacji miedzy nimi. Ilustracja kartograficzna jest wymierna i w pełni porównywalna. Ukazanie trwałości, względnie zmienności historycznych konfiguracji granicznych stanowić może punkt wyjścia do konstruowania postulatów ich weryfikacji przestrzennej, a nawet proponowania nowych paradygmatów terytorialnych. Projekty te ukazywane są na mapach o różnej szczegółowości i niejednolitej formie przekazu. Mają one wobec aktualnej rzeczywistości politycznej często postać rewizjonistyczną, zmierzając do zmiany dotychczasowego 
porządku geopolitycznego. Kryją się za nimi wyraźnie ukształtowane opcje światopoglądowe, bazujące na ekspansjonizmie i doktrynach imperialnych bądź na ruchach wyzwoleńczych i insurekcjach powstańczych. Mapa staje się inspiracją oraz ważnym orężem ideologicznym i propagandowym stosowanym do osiagania celów politycznych. Wykorzystywane ujęcia kartograficzne różnią się realnością i możliwościami realizacyjnymi. Niektóre z nich od początku są utopijne i odbiegają od realiów otaczającej rzeczywistości geopolitycznej. Takie też są interesujące, gdyż odzwierciedlają nastawienie ideowe ich kreatorów i zwolenników.

Tworzenie i rozpowszechnianie map geograficznych, na których autorzy kreślili linie postulowanych przez nich nowych rozgraniczeń politycznych, uzasadniane było przez projektodawców względami prawnymi, historycznymi, etnicznymi, strategicznymi czy demograficznymi. Dołączona do nich strona z wyjaśnieniem była na różnym poziomie merytorycznym. Tego rodzaju mapy pojawiały się w okresie wojen i przesileń politycznych i ilustrowały stanowiska państw lub pojedynczych myślicieli, zmierzających do rewizji dotychczas istniejących granic politycznych. Trafność ich prognoz była różna, ale zazwyczaj mijała się z realiami późniejszych działań militarnych. Jedynie sporadycznie potrafiły trafnie przewidzieć przyszłość. Niemniej ich wartość z punktu widzenia poznawczego jest ważna dla zrozumienia przyczyn i skutków wszelkich przesunięć rozgraniczeń politycznych. Obecnie, z perspektywy odległego już czasu, łatwo ocenić ich walory naukowe i stopień przewidywalności.

Po likwidacji państwa polskiego i jego zniknięciu z mapy Europy pod koniec XVIII w. polscy działacze niepodległościowi kreowali różne wizje restytucji Rzeczypospolitej. Stanął więc na porządku dziennym problem graniczny. Zaczęto się zastanawiać nad przebiegiem nowych granic i określeniem zasięgu geograficznego przyszłej Polski. Społeczeństwo polskie w okresie rozbiorowym miało silne przekonanie o trwałości państwa i możliwości powrotu do granic historycznych z 1772 r. Uważano, że jest to podstawowy warunek naprawy niesprawiedliwości i krzywdy moralnej, jakie spotkały naród polski. Tego typu marzenia odzwierciedlały się w wielu wypowiedziach, dokumentach oraz w ujęciach kartograficznych. Na wielu wykreślonych mapach odtwarzano ziemie polskie w granicach historycznych sprzed pierwszego rozbioru. Niewiele to miało wspólnego z rzeczywistością. Układ granic politycznych, rozczłonkowujący terytorium dawnej Rzeczypospolitej, ustalony ostatecznie na kongresie wiedeńskim w 1815 r., nie był kwestionowany przez mocarstwa europejskie i w miarę upływu czasu ulegał petryfikacji. Trzy państwa zaborcze stały na stanowisku ich niezmienności. Im bardziej Polacy kwestionowali ten stan, tym bardziej wzmacniało to sojusz państw zaborczych. Przypominanie o wielkiej terytorialnie Rzeczypospolitej i jej granicach politycznych miało wyłącznie charakter symboliczny i nie przekładało się na ówczesne przetasowania geopolityczne w Europie. Mit o możliwościach odbudowy zlikwidowanego państwa mobilizował jedynie społeczeństwo polskie do działań powstańczych i spiskowych, których efekty były wprost odmienne od oczekiwanych.

Wśród świattych elit społeczeństwa polskiego istniało mocno utrwalone przekonanie o istnieniu jednolitego narodu polskiego zamieszkującego zwarcie terytorium od Bałtyku i Warty po Berezynę i Dniepr ${ }^{1}$. Zdawano sobie sprawę z niejednolitości religijnych i językowych

\footnotetext{
${ }^{1}$ W odezwie ogtoszonej w 1836 r. czytamy: „Ukrainiec, Kaszub, Rusin, Wielkolub Małopolanin, Litwin, Podolanin, Żmudzin, Mazur, Wołynianin i jakiej bądź ziemi dawnej Rzeczypospolitej syn, jest Polakiem i w tym jedynie nazwisku całość naszą widzimy", R. Wapiński, Polska i małe ojczyzny Polaków. Z dziejów ksztattowania się świadomości narodowej w XIX i XX wieku po wybuch Il wojny światowej, Wrocław 1994, s. 59-60.
} 


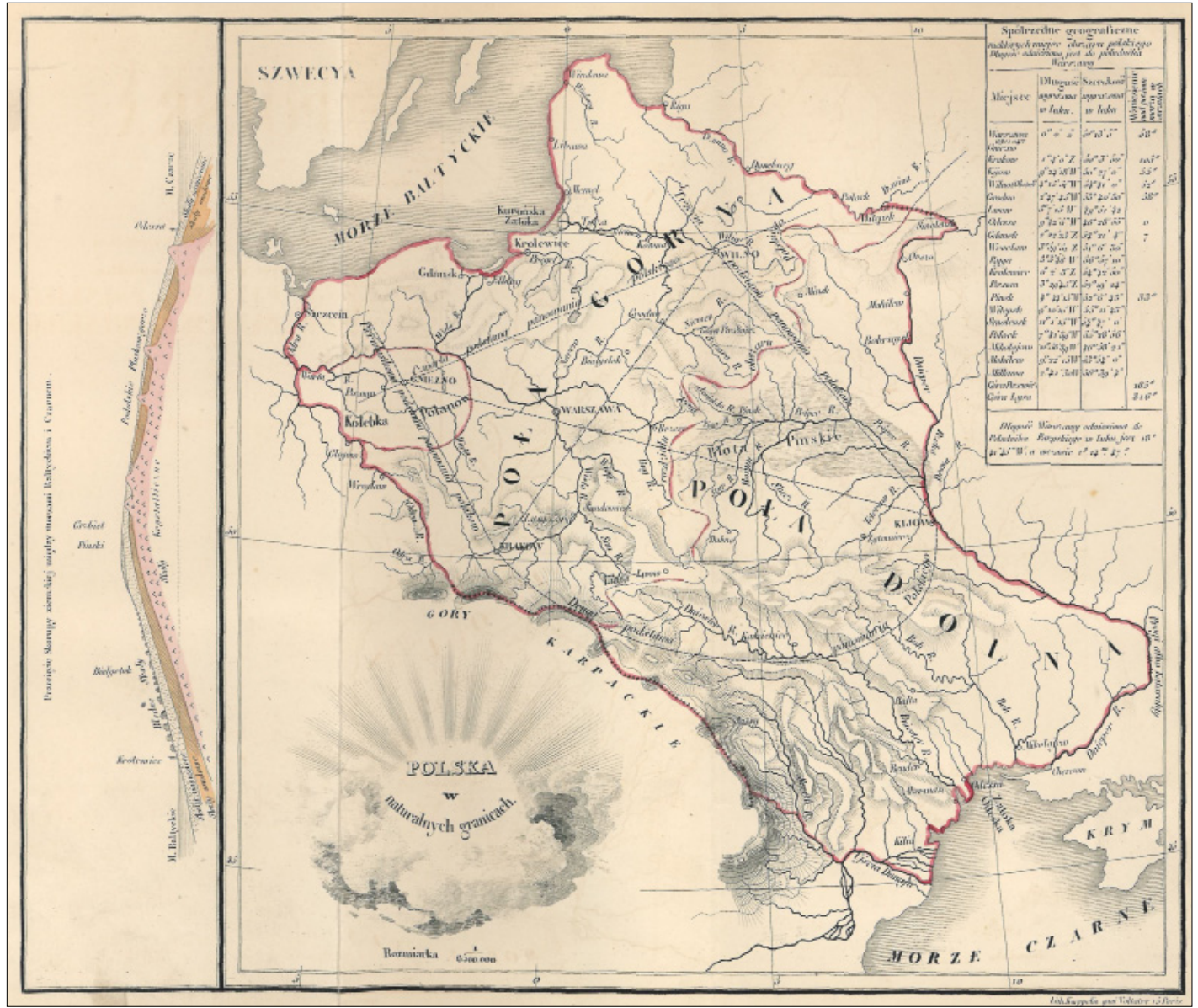

Ryc. 1. Mapa "Polska w naturalnych granicach” z książki 0. Żebrowskiego.

Żródło: 0. Żebrowski, Polska. Ogólny zarys przyczyn wzrostu i upadku dawnego państwa polskiego, Paryż 1847

w warstwie chłopskiej, a nawet z istnienia pewnych klasowych antagonizmów, ale były one ignorowane. $\mathrm{Na}$ terytorium całej Rzeczypospolitej ukształtował się jeden polityczny naród szlachecki, który był nośnikiem tradycji i wierności dawnej spuściźnie narodowej. Dążono do odrodzenia państwa w granicach z 1772 r. Wierzono, że istnieje wspólnota narodowa obejmująca trzy części składowe Rzeczypospolitej, a mianowicie Koronę, Litwę i Ruś. Granice zaś miedzy nimi nie odgrywają żadnej roli. Traktowano granice przedrozbiorowe jako postulat raczej minimalny, gdyż takie miasta jak Kijów czy Smoleńsk, utracone jeszcze w drugiej połowie XVII w., zaliczano powszechnie do miast polskich. Tego typu maksymalistyczne wyobrażenia były mocno utrwalone wśród polskiej elity przywódczej. Poglądy te były podzielane w kraju i na emigracji, w tym również w otoczeniu ks. Adama Czartoryskiego w Paryżu.

Czołowym reprezentantem tego obozu politycznego był m.in. Oskar Żebrowski², autor książki pt. Polska. Ogólny zarys

\footnotetext{
${ }^{2}$ Oskar Żebrowski urodził się w 1809 r. w Jurborgu (obecnie Jurbarkas) na Litwie. Brał udział w powstaniu listopadowym. Po jego klęsce udał się do Francji. W Paryżu ukończył studia politechniczne. Pracował następnie jako inżynier przy budowie dróg i mostów. Współpracował z polską emigracją
} 
przyczyn wzrostu i upadku dawnego państwa polskiego ${ }^{3}$. Integralną częścią tego opracowania jest zamieszczona w nim mapa pt. Polska w naturalnych granicach. Tak książka, jak i mapa ze względu na oryginalność konceptualną, jak również zawarte $\mathrm{w}$ nich posłanie ideowe to dzieła wyjątkowe. Autor wykorzystał głównie argumenty i kryteria geograficzne. Dało mu to możliwość zweryfikowania granic z 1772 r. na rzecz nowego układu terytorialnego Polski, zapewniającego - według rozumowania autora - siłę i bezpieczeństwo przyszłej odrodzonej Rzeczypospolitej. Nie pominął zaszłości historycznych, a nawet wprost przeciwnie - były one dla niego determinujące i dlatego też włączył w granice państwa polskiego nawet te obszary, które były z nim związane bardzo krótko. Niemniej, przy ustalaniu konkretnego przebiegu granic, preferował czynniki geograficzne, a mianowicie układ sieciowy rzek. W ogólnym zarysie kształt i wielkość przyszłego państwa polskiego zaprojektowanego przez Żebrowskiego przypominają historyczną Rzeczpospolitą z okresu jej świetności i potęgi.

Według Żebrowskiego Europa podzielona jest na dwie części. Wyjaśnia on położenie geograficzne Polski następująco: „Kto spojrzy na kartę Europy, łatwo dostrzeże, że ląd ten podzielony jest na dwie różne części; linia najkrótszej odległości między dwoma morzami Bałtyckiem i Czarnem, tącząca najniższy punkt Kurońskiej Zatoki, którą Niemcy Curische-Haf przezwali, z najwyższym punktem zatoki Odeskiej, a przechodząca przez błota Pińskie, jest linią dwie te części odróżniającą. - Z lewej strony tej linii jest Europa Południowo Zachodnia, z prawej zaś jest Północno Wschodnia. [...] Kierunkiem

\footnotetext{
patriotyczną, w tym działał w paryskim Towarzystwie Literackim. Zmarł w 1883 r. pod Tuluzą.

${ }^{3}$ Książkę Żebrowskiego i zawartą w niej mapę dokładnie omówił i skomentował Leszek Sykulski, Oskar Żebrowski - prekursor polskiej geopolityki, „Przegląd Geopolityczny”, 2, 2010, s. 169-174. Według opinii tego autora Żebrowskiego można zaliczyć do czołowych prekursorów polskiej geopolityki.
}

linii, o której wyżej mówiliśmy, rozdzielającej Europę na dwie różne części, jest umieszczony obszar naturalny Polski; na jego to przestrzeni znajduje się sparcie tych sprzecznych interesów. [...] Obszar więc ten na ciągłe narażony jest ciosy ze strony Rosji. [...] Wstrzymywać napady Rosji i być w tej części Europy ogniskiem liberalnych wyobrażeń, jest bez wątpienia wielkim obowiązkiem"4.

Równocześnie autor zwraca uwagę na strategiczne usytuowanie Polski otoczonej czterema ekspansywnymi nacjami: „Polska czterema różnymi narodowościami otoczona była; każda z nich silne wywierała parcie. - Z lewej strony germanizm pochłonąwszy ludy słowiańskie Zakarpackie, nie parł na Polskę od Karpat, bo tam naturalna granica zdaje się zaporą mu była; lecz działanie jego wywierało się od Odry, gdzie żaden wał silny nie oddzielał go od nas. Od strony północnej, waleczni Szwedzi zajmowali nie tylko naturalny obszar półwyspu Skandynawskiego, lecz większą część brzegów Bałtyku. Z prawej strony, to jest za Dźwiną i Dnieprem była Moskwa. [...] Polska $\mathrm{z}$ tej strony nowego znalazła nieprzyjaciela w Moskalu; - lecz wielkość Polski, jej potęga materialna i moralna trzymały długo Moskalów na wodzy. Ze strony południowej idea islamizmu nachodzita"s.

W ramach kontynentu europejskiego Polska, według Żebrowskiego, zajmuje pozycję specyficzną, gdyż rozciąga się na pomoście bałtycko-czarnomorskim ${ }^{6}$. Posiada ona szeroki dostęp do Bałtyku, gdyż obejmuje w całości wybrzeże morskie od ujścia Odry do ujścia Dźwiny. Polskimi portami są: prawobrzeżny Szczecin, Gdańsk, Królewiec, Memel, Libawa i Windawa. W obrębie ziem polskich znajdują się zachodnie

\footnotetext{
${ }^{4}$ 0. Żebrowski, Polska. Ogólny zarys przyczyn wzrostu i upadku dawnego państwa polskiego, Paryż 1847, s. 46, 49.

${ }^{5}$ Tamże, s. 58

${ }^{6}$ Koncepcje pomostowego położenia Polski między Bałtykiem a Morzem Czarnym rozwinął następnie Eugeniusz Romer, Przyrodzone podstawy Polski historycznej, Lwów 1912.
} 
Pomorze, utracone w XII w., następnie Pomorze Gdańskie, Prusy Wschodnie oraz cała Kurlandia.

Podobnie znaczący ma mieć dostęp przyszła Polska do Morza Czarnego, a mianowicie obejmować ma ona całe wybrzeże morskie od ujścia Dunaju do ujścia Dniepru. Lądowe granice państwa polskiego mają być wytyczone nurtem rzek. Przejawia się tu u autora wyraźny dogmatyzm i determinizm geograficzny. Granica zachodnią ma być przebieg rzeki Odry, począwszy od Karpat, a kończąc na Zalewie Szczecińskim. Przez ten sztuczny podział dzieli historyczny Śląsk na dwie połowy, z których tylko część północno-wschodnią włączono w skład Polski ${ }^{7}$. Traktując układ wielkich rzek jako najważniejszą barierę fizjograficzną, Żebrowski dostrzegał w ich przebiegu podstawę do wyznaczenia granicy politycznej także z imperium rosyjskim. Rozgraniczenie to proponował ustalić na linii Dźwiny i Dniepru.

W tak szeroko zakrojonych granicach traktuje Żebrowski Polskę jako odrębną krainę naturalną. Uzasadnia to następująco: „Między Dniestrem i Dźwiną z jednej strony, a Odrą, Karpatami i ujściem Dunaju z drugiej, znajduje się pas lądu europejskiego, oparty równie o Bałtyckie jak o Czarne morze. - Pas ten stanowi Obszar, który [...] jest razem krainą naturalną. [...] Obszar nasz w granicach jakeśmy mu naznaczyli, stanowi pełną i nierozdzielną całość. Zresztą dzieje ludu polskiego słusznie dają prawo nazwania Obszarem polskim tę część lądu"8.

Wydzielony obszar Polski, liczący około miliona $\mathrm{km}^{2}$, Żebrowski dzieli na dwie połowy (tzw. poły). Jedna z nich to zlewisko Bałtyku, druga z nich to zlewisko Morza Czarnego. Do pierwszego z nich płyną: Odra, Wisła, Niemen i Dźwina. Natomiast w kierunku południowo-wschodnim, do

${ }^{7}$ Sztuczny podział Śląska był krytycznie oceniany przez późniejszych badaczy, zob. F. Bujak, Oskar Żebrowski i jego pogląd na dzieje Polski, Kraków 1936, s. 12.

${ }^{8}$ 0. Żebrowski, Polska, s. $12-14$
Morza Czarnego, cztery rzeki, a mianowicie: Prut, Dniestr, Boh i Dniepr. Na terytorium Polski zaznaczono cztery miasta odgrywające duże znaczenie w dziejach kraju: Gniezno, Kraków, Kijów i Wilno. Między tymi miastami Żebrowski zakreślił linie - cztery z nich o przebiegu prostym, które łączyły Gniezno z Krakowem, z Kijowem i z Wilnem oraz Kraków z Wilnem oraz następnie jedną lekko zaokrągloną linię łączącą Kraków z Kijowem. Utworzony czworobok między Gnieznem, Krakowem, Kijowem i Wilnem uznał za „podstawę panowania Polaków”. Pierwsza z tych podstaw łączyła Gniezno z Krakowem, druga Kraków z Kijowem, trzecia Wilno z Kijowem, czwarta zaś Gniezno z Wilnem. Ta geometryczna figura miała swoją merytoryczną wymowę. Autorowi chodziło o pokazanie w ujęciu czasowym powiększania się w ciągu wieków zasięgu terytorialnego państwa polskiego.

Dzieło Żebrowskiego, a zwłaszcza dołączona do tekstu mapa, są bardzo interesujące $\mathrm{z}$ powodu oryginalności formy i treści. Pomimo swoich walorów spotkały się z późniejszą krytyką ze strony geografów i historyków. Ci pierwsi zaznaczali, że przyjęcie jedynie kryteriów hydrologicznych oraz częściowo geologicznych doprowadziło do schematyzmu i deformacji. Rzeka zazwyczaj nie jest barierą dzielącą narody i państwa. Bywa często odwrotnie i miasta położone nad rzekami wytwarzają regiony naturalne i prowincje polityczne obejmujące obszary dorzeczy po obu stronach rzeki. Zarzuty historyków były również uzasadnione merytorycznie. Przede wszystkim zwracano uwagę na maksymalizm i brak realizmu. Odepchniecie Niemców za Odrę, likwidacja Prus Wschodnich oraz równoczesne pozbawienie Rosji wszelkich zdobyczy oraz opanowanie szerokiego pobrzeża czarnomorskiego to już były pomysły utopijne, prawie abstrakcyjne, niewiele mające wspólnego z ówczesną rzeczywistością polityczną. Należy jednak zaznaczyć, że współcześni Żebrowskiemu 
Polacy potraktowali jego propozycje poważnie i z uznaniem. Zastrzeżenia miały charakter drugorzędny i dotyczyły za bardzo uproszczonej granicy wschodniej i rezygnacji z obszarów położonych na wschód od Dniepru.

Nadmieniono już, że propozycja Żebrowskiego odbiegała od powszechnie głoszonych opinii, gdyż we wszystkich dokumentach oraz publicznych wypowiedziach aż do powstania styczniowego twierdzono, że jedynym słusznym rozwiązaniem jest powrót do granic z 1772 r. Idea restytucji Rzeczypospolitej w tym jedynie kształcie stanowiła program oczywisty i niewzbudzający kontrowersji. W miarę upływu kolejnych dziesięcioleci XIX w. ta wydawałoby się niekwestionowana opinia zaczęła być wśród światlejszych Polaków podawana w wątpliwość. Nie wpłynęły na to uwarunkowania międzynarodowe. Te były stałe i żadne z mocarstw europejskich nie brało pod uwagę odbudowy nawet szczątkowej Polski, a tym bardziej dużego terytorialnie i suwerennego państwa polskiego. Wpłynęły na tę zmianę postrzegania otaczającej rzeczywistości procesy emancypacji mas ludowych, zachodzące w ramach granic historycznej Rzeczypospolitej. Kwestia składu narodowościowego i zróżnicowania etnicznego tego dużego terytorium geograficznego była w zasadzie niedostrzegana. Zdawano sobie sprawę z odmiennej specyfiki poszczególnych prowincji, zwłaszcza Litwy i Rusi. Zakładano, że ewentualne układy o charakterze federacyjnym rozwiążą istniejące różnice kulturowe w sposób kompromisowy. Dopiero w drugiej połowie wieku XIX, a w zasadzie na przełomie XIX i XX w. zdano sobie sprawę, że dotychczasowe opinie o jednolitości narodowej ziem Rzeczypospolitej wymagają przewartościowania.

Powstawanie idei narodowych i tworzenie się odrębności etnicznej w warstwie chłopskiej było procesem stopniowym. Dotyczyło to zwłaszcza środkowo-wschodniej
Europy, będącej obszarem o niskim poziomie oświaty i zacofanej gospodarce. Z dużym opóźnieniem, gdyż dopiero w końcu XIX w., idee narodotwórcze dotarły na wschodnie kresy Rzeczypospolitej. Zaczęły powstawać podwaliny odrodzenia narodowego wśród ludności chłopskiej posługującej się językami ukraińskim, białoruskim i litewskim. W momencie dotarcia do ludu haseł o charakterze nacjonalistycznym, jednolity dotychczas obszar wschodniej Rzeczypospolitej zaczął się różnicować. Powstał dylemat nie tyle naukowy, co bardziej polityczny. Rzesze szlacheckie były nadal związane z językiem polskim i one kultywowały tradycje jedności. Natomiast wśród warstwy chłopskiej stawały się popularne hasła odrębności bazującej na odmiennym języku, względnie religii. Proces ten miał charakter uniwersalny i przeciwdziałanie mu nie przynosiło oczekiwanych skutków. Wymagało to weryfikacji istniejących stereotypów i odmiennego spojrzenia na granice przyszłego państwa polskiego. Na terytorium dawnej Rzeczypospolitej zaczęły powstawać obszary różniące się charakterem etnicznym. Rozgraniczenie ich nie zawsze jest łatwe. Kształtowały się szerokie pogranicza, na których żyła ludność mająca kłopoty z własną identyfikacją. Pojawiały się zwłaszcza tam, gdzie granice zasięgów religijnych nie były zbieżne z granicami lingwistycznymi.

Przed środowiskiem polskich geografów oraz publicystów zajmujących się demografią etniczną stanął niezmiernie złożony problem badawczy, mający konsekwencje polityczne, a mianowicie określenie zasięgów językowo-religijnych. Dotyczyło to głównie ludności zamieszkującej obszary wschodnie historycznej Rzeczypospolitej, nieposługującej się językiem polskim i nieidentyfikującej się z polskością. W miarę upływu czasu kwestia ta stawała się coraz bardziej przejrzysta, co wynikało z upowszechnienia badań statystycznych o charakterze masowym. Stopniowo wyznaczono na terytorium 
historycznej Rzeczypospolitej obszary o przewadze ludności polskiej, ukraińskiej, białoruskiej, litewskiej czy niemieckiej. Równocześnie uświadomiono sobie, że poza granicami z 1772 r. znajdują się tereny, na których przeważająca część mieszkańców używa w życiu codziennym języka polskiego. Dotyczyło to Górnego Śląska i Śląska Cieszyńskiego, ziemi mazurskiej. Wszystko to razem wymagało odmiennego spojrzenia na kształt terytorialny przyszłego państwa polskiego.

W społeczeństwie polskim w końcu XIX w. zaczęły funkcjonować nowoczesne partie polityczne. Wszystkie z nich z wyjątkiem skrajnie lewicowych stawiały za cel swojego działania odbudowę utraconej państwowości. Z dużym dystansem odnosiły się one do kwestii granicznych, drażliwych ze względu na opresyjną działalność zaborców, ale też z powodu braku jednolitości w poglądach ich członków co do zasięgu terytorialnego i charakteru ustrojowego projektowanego państwa. Nie pogodzono się z utratą mieszanych narodowościowo kresów wschodnich. Zakładano powstanie nieokreślonych układów federacyjnych. Sprawę tę odkładano i nie składano wiążących deklaracji. Jedynym ugrupowaniem, które tę sprawę postrzegało w sposób w miarę konsekwentny i jednoznaczny był ruch narodowy. Tacy działacze jak Ludwik Popławski, a następnie Roman Dmowski mieli w tej kwestii stanowisko przemyślane i potrafili je logicznie uzasadnić. Uważali, że powrót do granic z 1772 r. jest nie tylko całkowicie nierealny, ale dążenie do tego stanu jest anachroniczne i szkodliwe. Nie wysuwali roszczeń maksymalistycznych. Zmierzali do zapewnienia spoistości i siły państwa. $\mathrm{Z}$ tego też powodu kwestią nadrzędną były dla nich granice zachodnie. Przyszłość Polski związana musiała być $\mathrm{z}$ dostępem do morza, odzyskaniem części piastowskiego Śląska oraz Wielkopolski, Pomorza i południowej części Prus Wschodnich. W dużym stopniu byli prekursorami idei „piastowskiej Polski”, której trzonem zasadniczym miały być etniczne ziemie polskie położone na zachodzie. Nie znaczy, że byli zwolennikami „etnicznej Polski” i rezygnacji z dużej części kresów wschodnich. Mieszane narodowościowo tereny zabużańskie z Wilnem, Grodnem, Lwowem a nawet z Mińskiem powinny być składową częścią Polski. Natomiast nawoływanie o granice na Dnieprze traktowali jako rzecz nieodpowiedzialną. Byli więc zwolennikami koncepcji pośredniej, w której równocześnie wykorzystywali do wykreślania granic przyszłej Polski kryteria historyczne i etniczne.

Koncepcja „etnicznej Polski” i ograniczenia terytorium kraju jedynie do obszaru, gdzie ludność narodowości polskiej przekracza 50 proc. zaludnienia, nie była zbyt popularna wśród polskich działaczy. W tych wyliczeniach ujmowano jedynie ludność wiejską, gdyż we wszystkich miastach historycznej Polski dominowała ludność polska i żydowska. Przy takim założeniu problematyczna stawała się przynależność państwowa nawet wiejskich okolic Białegostoku, Chełma czy Przemyśla.

Do prekursorów idei etnicznej Polski należał m.in. Bolesław Wysłouch. W pracy opublikowanej w 1886 r. stwierdzał, że Polska w granicach z 1772 r. była państwem szlacheckim, natomiast przyszłość należy do ludu i to on będzie decydował o granicach. Podstawowym zadaniem, według jego koncepcji, było jedynie zjednoczenie ziem zamieszkałych przez mieszkańców narodowości polskiej. Przyszła Polska powinna być państwem jednego narodu i jednego języka9. Przy tym założeniu terytorium państwa polskiego powinno być ograniczone do Królestwa Polskiego, z wyjątkiem północnej części guberni suwalskiej. Ponadto włączał ewentualnie do przyszłej Polski zachodnie powiaty guberni

\footnotetext{
${ }_{9}^{9}$ B. Wysłouch, Szkice programowe, „Przegląd Społeczny”, (6), 1886, s. 395493. W pewnym stopniu wizja Wysłoucha była prorocza i spełniła się po 1945 r., ale wymagała gigantycznych przesiedleń ludności, która musiała się dopasować do granic arbitralnie wyznaczonych przez wielkie mocarstwa.
} 
grodzieńskiej, w których dominowała ludność katolicka. W składzie odrodzonej Polski widział również zachodnią Galicję po rzekę San i północną część Śląska Cieszyńskiego. Bardziej ambitne roszczenia wysuwał wobec Niemiec. Jego dezyderaty dotyczyły południowo-wschodniej części Ślaska, Prus Wschodnich i Zachodnich oraz Poznańskiego.

Koncepcje Wysłoucha nie znalazły oddźwięku wśród geografów polskich. Były na ówczesne czasy trudne do zrozumienia. W końcu XIX w. nie uważano jeszcze Ukraińców czy Białorusinów za odrębne narody godne posiadania państwa narodowego. Dlatego też w dalszych wizjach terytorialnych, których było coraz więcej, preferowano koncepcje wielokryteriowe. Nadal ważne było nawiązywanie do historii i dorobku kulturowego. Coraz powszechniej odchodzono jednak od granic z 1772 r. Poszerzanie wiedzy o stosunkach etnicznych także weryfikowało spojrzenie na granicę wschodnią Polski. Na przykład Wileńszczyznę czy Grodzieńszczyznę włączano coraz częściej do etnicznego obszaru Polski, a nie Litwy czy Białorusi. Przed pierwszą wojną światową oraz w jej trakcie coraz ważniejsze stawały się kryteria nie tylko etniczne, ale i strategiczne ${ }^{10}$.

Projektodawca, który przy postulowaniu przyszłych granic politycznych Polski całkowicie pominął kryteria historyczne i przyjął jednie etniczne, czyli zasięg zwartego polskiego obszaru narodowego, był znany działacz polityczny, literat, krajoznawca i publicysta Czesław Jankowski ${ }^{11}$.

\footnotetext{
${ }^{10}$ Różnorodne wizje i koncepcje zostały omówione w książce autora, więc nie wymagają przypomnienia. Opracowanie to zawiera liczne mapy ukazujące postulowane granice Polski, m.in.: Eugeniusza Romera, Wtodzimierza Wakara, Wiktora Skargi-Dobrowolskiego, Adama Szelągowskiego, Józefa Jaskólskiego, P. Eberhardt, Polska i jej granice. Z historii polskiej geografii politycznej, Lublin 2004.

${ }^{11}$ Czesław Jankowski urodził się w 1857 r. w Oszmianie. Mieszkał głównie w Wilnie oraz w Warszawie. W 1906 r. uzyskał mandat do rosyjskiej Dumy. Był poetą i powieściopisarzem. Współpracował z wileńskim „Głosem Polskim”, a następnie z konserwatywnym "Stowem”. Był autorem następujących książek: Po Europie (1893), Powiat oszmiański (1896-1900), Sześćset lat stosunków polsko-pruskich (1902), Naród polski ijego ojczyzna (1914). Zmart w 1929 r. w Wilnie.
}

$\mathrm{Na}$ początku pierwszej wojny światowej napisał broszurę pt. Polska etnograficzna, która zawierała mapę pod tym samym tytułem. 30 sierpnia 1914 r. rosyjska cenzura wydała zgodę na publikację i rozpowszechnianie. Przypuszczalnie była to inicjatywa autora, ale nie można wykluczyć pewnej inspiracji ze strony władz rosyjskich. Miało to miejsce bezpośrednio po manifeście do narodu polskiego naczelnego wodza wojsk rosyjskich wielkiego księcia Mikołaja Mikołajewicza, który zapowiadał zjednoczenie ziem polskich pod berłem cesarza rosyjskiego. Broszura Jankowskiego była w pewnym sensie odpowiedzią na odezwę rosyjską. Znając drogę życiową Jankowskiego, nie można przypisywać mu złych intencji i braku patriotyzmu. Był niewątpliwie przekonany, że pozytywne przyjęcie manifestu rosyjskiego jest zgodne z narodowymi interesami Polski. Zakładał, że Rosja wygra wojnę i jedynie to państwo będzie decydowało o losach Polski. Da to szanse zjednoczenia kraju i włączenia do niego ziem zamieszkałych przez Polaków, a znajdujących się w Niemczech i w Austrii. Ze względów taktycznych Jankowski nie poruszył delikatnej sprawy pełnej suwerenności państwa. Twierdził, że „Polska powinna być wskrzeszona i związana z Rosją unią personalną" ${ }^{12}$.

$\mathrm{Na}$ wykreślonej mapie czerwoną linią Jankowski wytyczył granice projektowanej Polski, choć te na wschodzie nie zostały pokazane identycznie jak na zachodzie, co by pośrednio wskazywało na przynależność autonomicznej Polski do Wielkiej Rosji. Autor bardzo wyraźnie zaznaczył, że przy wyznaczeniu granic kieruje się względami wyłącznie etnicznymi (etnograficznymi). Na podstawie tego założenia do Polski włączył tylko te tereny, na których większość ludności posługuje się językiem polskim. Jedynym wyjątkiem był Gdańsk wraz z bliskim zapleczem, który pomimo jego niemieckiego oblicza został zaliczony do tzw.

\footnotetext{
${ }^{12}$ Cz. Jankowski, Polska etnograficzna, Warszawa 1914, s. 3.
} 


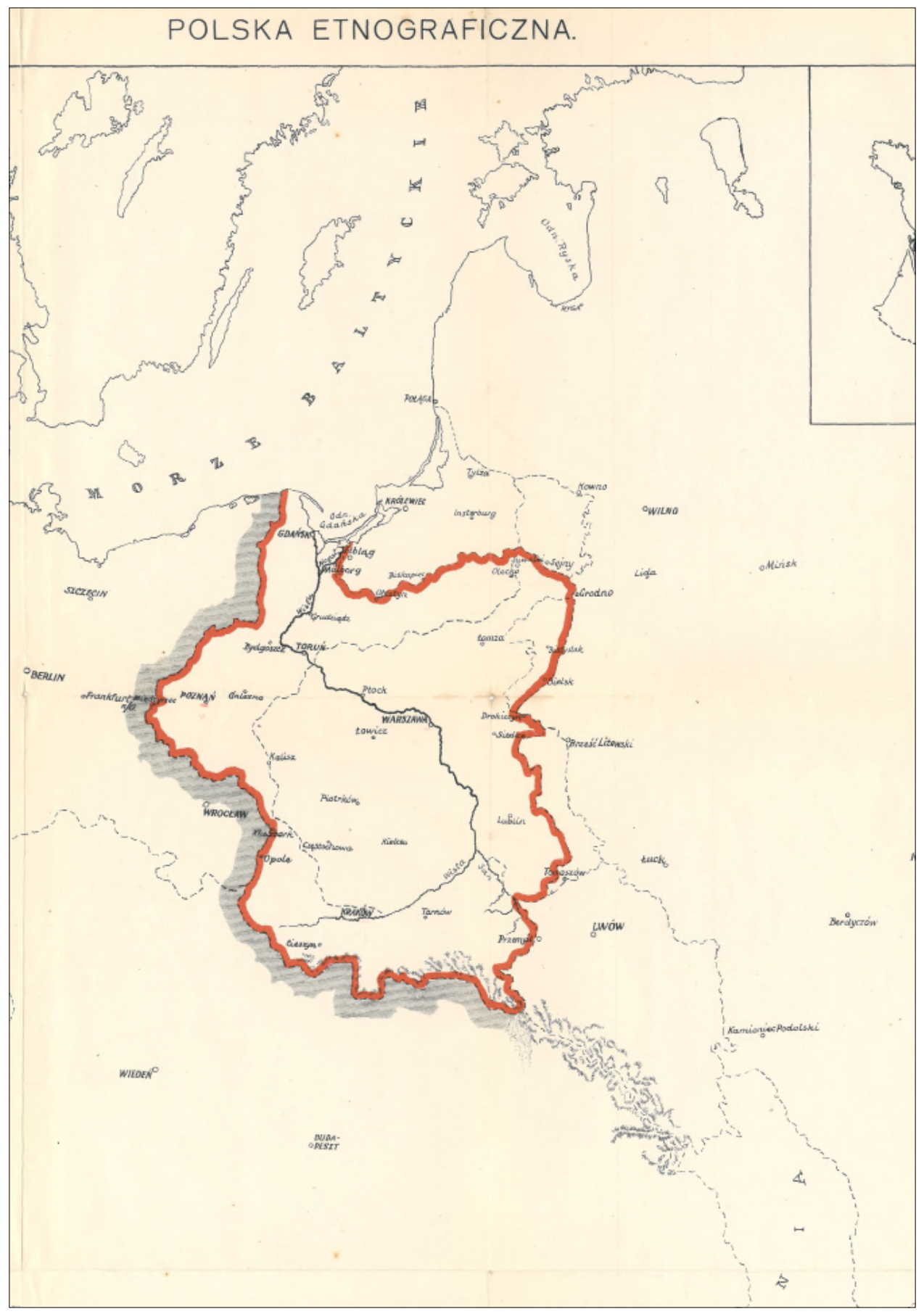

Ryc. 2. Mapa "Polska etnograficzna” z książki Cz. Jankowskiego.

Żródło: Cz. Jankowski, Polska Etnograficzna, Warszawa 1914 
Polski etnograficznej. Jankowski tłumaczył to koniecznością dostępu do morza.

Integralną częścią Polski na zachodzie miało być Wielkie Księstwo Poznańskie oraz tzw. Prusy Zachodnie. Autor zweryfikował tu na niekorzyść Polski granicę z 1772 r. dowodząc, że niewielka część terenów zachodniego pogranicza uległa germanizacji i zatraciła oblicze polskie. Natomiast przeprowadził znaczną korektę na korzyść Polski na południe od Wielkopolski, odłączając od Niemiec Górny Śląsk i Opolszczyznę. Zaproponował następujący przebieg granicy: „Poniżej Poznania granica nasza obejmuje ludność polską na Śląku, czyli obwód regencyjny Opolski i część niedużą obwodu Wrocławskiego. Szmat to ziemi jeszcze Piastowskiej, rdzennie polskiej, zgermanizowanej, a od czasów pamiętnego kulturkampfu, odniemczanej z wielkim powodzeniem przez polskich gorących agitatorów o typie np. niezapomnianego Karola Miarki. Linia graniczna Śląska biegłaby od Krotoszyna na Brzeg do Prądni (Neustadt), a potem do granicy austriackiej przy Ostrawie Morawskiej (Mährisch Ostrau). Od Ostrawy Morawskiej rozpocznie się linia graniczna, oddzielająca polaków od czechów [sic], a wkluczająca do Polski etnograficznej tzw. Księstwo Cieszyńskie. Z Ostrawy pobiegnie, domniemanie przez Jabłonków, oprzeć się o obecną granicę Galicji i tą granicą pójdzie do Piwnicznej lub Muszyny, aby zwrócić się na północ przez Rymanów ku Datnowowi nad Sanem"13.

Postulowane przez Jankowskiego granice zachodnia i południowa Polski były znacznie bardziej korzystne, niż te, które Polska uzyskała w traktacie wersalskim, a tym bardziej od istniejącej w $1772 \mathrm{r}$. Odnosiło się to zwłaszcza do wspomnianego tzw. niemieckiego Śląska oraz Śląska Cieszyńskiego.

Poważnym i mającym konsekwencje dla autora problemem było takie wyznaczenie granicy wschodniej Polski, aby

${ }_{13}$ Tamże, s. 6. usatysfakcjonowało to urzędujące w Warszawie władze rosyjskie, a jednocześnie nie naraziło go na ostracyzm ze strony polskiej opinii publicznej. Ten pierwszy warunek był ważniejszy, gdyż determinował publikację. Najbardziej drażliwa była przynależność Chełmszczyzny, która w 1912 r. pomimo sprzeciwów Polaków została odłączona od Królestwa Polskiego. Było wiadomo, że cenzura rosyjska nie zaakceptuje propozycji sprzecznej z tą decyzją. Zdając sobie z tego sprawę, Jankowski przeprowadził granicę tak, aby takie miasta jak Tomaszów Lubelski, Chełm i Biała Podlaska znalazły się poza wytyczoną granica przyszłej Polski. Podobnie „ruski Przemyśl” pozostał w Rosji. Wzbudziło to oburzenie wśród społeczeństwa polskiego. Przyjęto, że tego typu poglądy są wyrazem kapitulanctwa i serwilizmu wobec zaborcy ${ }^{14}$.

Granica wschodnia miała według projektu Jankowskiego charakter południkowy, ale dość nieregularny i rozciągała się od Karpat do Suwalszczyzny. Tam też w okolicach Filipowa docierała do Prus Wschodnich. Dla wierności przekazu warto przytoczyć tekst autora: „Potem już wzdłuż Sanu, oddzielającego dzielnice etnograficzne polskie od dzielnic rusińskich, pójdzie mniej więcej aż do ujścia Wisłoki, aby w okolicach Tarnogrodu wstąpić na dzisiejszą południową granicę Królestwa

\footnotetext{
${ }^{14}$ W piśmie „Świat” pojawiła się anonimowa ostra polemika o następującej treści: „Jeszcze na wiosnę zatrąbił on [tzn. Czesław Jankowski - P.E.] nam do odwrotu z Litwy i Rusi - a to pod pozorem ukrzepienia się w Polsce prawdziwej, Polsce etnograficznej, ostro wtedy wykazano mu całą nieścisłość, całą mętność, całe bałamuctwo pojęcia etnograficznej Polski. I niemal jednomyślnie P. Czesław Jankowski został za ten swój koncept przepędzony przez szeregi całej niemal prasy polskiej. To go nie otrzeźwiło. Pilno mu do nowych kataplazm. Wydaje oto nową broszurkę w tym samym duchu zawierającą tym razem - mapkę Polski etnograficznej. Co za smutna broszurka?! I iloma sprzecznościami upstrzona?! Miejscowości np. $075 \%$ polakach na południowym wschodzie znajdują się w tej mapie już poza granicami, natomiast jest w granicach Śląsk Opawski, gdzie żywioł polski stanowi parę procentów. Jest w tych granicach i Gdańsk. Ale Gdańsk ożywiony w momencie zaborów pięknem uczuciem państwowości polskiej nigdy etnograficznie nie był polskim. Było to zawsze miasto przepełnione niemcami. P. Czesław Jankowski o tem, ma się rozumieć wie. I w tym miejscu nagle po prestidigitatorsku zamiast etnograficznego wysuwa polityczny motyw, autonomiczna Polska musi mieć przecież przystęp do morza. Ale w takim razie po co wykosztowywać się na mapy »etnograficzne «", „Świat”, 26 IX 1914, nr 39).
} 
Polskiego. [...] Chełmszczyzna, terytorium nowo kreowanej guberni chełmskiej, pozostanie oczywiście poza granicami Polski etnograficznej. Tedy linia graniczna pójdzie pobrzeżem gub. chełmskiej, a dotknąwszy Bugu u Drohiczyna, zacznie obejmować etnograficzną połać, którą ongi Napoleon... zapomniał wcielić do Księstwa Warszawskiego. Połać tę stanowią zachodnie części dzisiejszych powiatów białostockiego i bielskiego gub. grodzieńskiej, wyraźmy się bardziej ogólnikowo: zachodnia część b. obwodu białostockiego, gdzie są odwieczne siedziby najautentyczniejszych mazurów. U samego Grodna zwraca się granica Polski etnograficznej silnie na zachód i, przecinając dzisiejszą gubernię suwalską między Suwałkami a Sejnami, odrzuca Litwie etnograficznej odwieczne siedziby Litwinów suwalskich"15.

Kierując się zasadami etnicznymi, Jankowski wysuwał roszczenia wobec południowych Prus Wschodnich. Uważając, że Rosja pokona Niemcy zakładał, iż zaistnieje możliwość włączenia do Polski protestanckich Mazur oraz południowej katolickiej Warmii, a także nadwiślańskiego Powiśla. Wówczas ludność tam mieszkająca używała języka polskiego. Była ona świadomościowo poważnie zgermanizowana (zwłaszcza na Mazurach), ale Jankowski, jak wielu ówczesnych Polaków, był przekonany, że po przyłączeniu jej do Polski nastąi jej szybka repolonizacja. Północny zasięg języka polskiego miał stanowić granicę państwa polskiego. Autor weryfikacje historycznej granicy Rzeczypospolitej z 1772 r. uzasadniał następująco: „Poczem wkroczymy mniej więcej w okolicach Filipowa na miedze graniczne etnograficznie polskiego "Kraju Mazurów« i miedzami temi, przyłączając do Polski etnograficznej cały pas mazurskiej ziemi, z Ełkiem, Olsztynem, Iławą, dotrzemy pod Grudziądz. Tu granica pobiegnie na północ równolegle z biegiem Wisły, przycinając atoli do
Polski etnograficznej taki pas ziemi, aby bez żadnej nigdzie przerwy cała Wisła od źródła do ujścia znalazła się na terytorium Polski etnograficznej. Powiedzmy przeto, że granica $\mathrm{w}$ tem miejscu pada ściśle na obecną linię kolejową Graudenz-Marienwerder-Marienburg. Malbork wszedłby w granice Polski etnograficznej, a linia graniczna pobiegłaby ku morzu wzdłuż rzeki Noteci. Wybrzeże morskie Polski etnograficznej sięgałoby przeto od ujścia Noteci do Pucka"'16.

Należy się zastanowić, czy zaprezentowana przez Jankowskiego koncepcja graniczna była realna, czy też od początku była mrzonką polityczną. Odpowiedź jest trudna, gdyż spełnienie jej zależało od całkowitego pokonania Niemiec i Austrii przez Rosję i opanowania przez armię carską wschodnich Niemiec, Galicji i Śląska. W takiej sytuacji mogłoby nastąpić częściowe zjednoczenie ziem polskich, które stałyby się autonomiczną prowincją rosyjską o większej lub mniejszej samorządności. Rozważania nad alternatywną historią nie mają jednak dużego sensu i nawiązanie do propozycji Jankowskiego ma jedynie walory interesujące $\mathrm{z}$ punktu widzenia poznawczego.

W niniejszym artykule przedstawiono i porównano ze sobą dwie wizje dotyczące przeszłości Polski i jej hipotetycznych granic opracowane przez dwóch polskich intelektualistów: Oskara Żebrowskiego i Czesława Jankowskiego. Obie dzieliło 67 lat. Pierwsza z nich powstała w 1847 r. w Paryżu, druga zaś w Warszawie w 1914 r. Powstały w całkowicie innych uwarunkowaniach politycznych. W międzyczasie zmieniła się sytuacja w Europie oraz na ziemiach polskich. Stosunki międzynarodowe w 1847 r. były stabilne i nie oczekiwano zmian. Z kolei w 1914 rozpoczęła się wojna, która musiała doprowadzić do rewolucyjnych przetasowań geopolitycznych w Europie. Polscy 
działacze polityczni w 1847 r., inaczej niż w 1914, postrzegali również terytorium, do którego Polacy mieli prawa moralne. W pierwszym okresie, jeszcze przed powstaniem styczniowym, nikt ze światłych Polaków nie miał wątpliwości, że Polska powinna się odrodzić w granicach z $1772 \mathrm{r}$. W 1914 r. kwestia ta była niejednoznaczna i niosła wiele kontrowersji. Wszystko to razem spowodowało, że obie analizowane koncepcje różnią się znacznie tak od strony ideowej, jak i terytorialnej. Historyczna Polska Żebrowskiego liczyła milion $\mathrm{km}^{2}$. Niewielka terytorialnie etniczna Polska Jankowskiego obejmowała obszar niecałych 200 tys. $\mathrm{km}^{2}$. Była więc ponad pięciokrotnie mniejsza, zaludnienie zaś czterokrotnie mniejsze. Trudno zatem porównywać rozległe terytorium położone między Bałtykiem a Morzem Czarnym do niewielkiego kadłubowego terytorium państwa polskiego położonego w dorzeczu Wisły.

$\mathrm{Na}$ mapie autorstwa Żebrowskiego mamy obraz mocarstwowej i wieloetnicznej Rzeczypospolitej, będącej wspólnotą wielu nacji, religii i języków. Druga mapa, wykreślona przez Jankowskiego, stawia postulat odbudowy niewielkiej, monoetnicznej Polski, kraju jednego narodu, w którym dominuje jedna religia i wspólny język, będącego w dodatku państwem o ograniczonej suwerenności wobec imperialnej i despotycznej Rosji. Mamy więc do czynienia $\mathrm{z}$ dwoma wariantami, jednym maksymalistycznym i drugim minimalistycznym. Na początku pierwszej wojny światowej ten drugi był bardziej prawdopodobny do zrealizowania. Pierwszy pozostawał anachroniczną mrzonką, nawiązującą jedynie do przeszłości.

Rzeczywistość polityczna, która ukształtowała się po zakończeniu działań wojennych, była dość zaskakująca i pomyślna. Trzy imperia zaborcze równocześnie poniosły klęskę. Powstała wyjątkowo korzystna koniunktura, w dużej mierze wykorzystana. Polska pojawiła się na mapie Europy w granicach wersalsko-ryskich. Odbiegała ona znacznie od propozycji Żebrowskiego i Jankowskiego. Pojawił się wariant pośredni, odległy od ambitnej wizji Żebrowskiego, ale nie ograniczony do małej etnicznej Polski Jankowskiego. Nowo powstałe państwo zajmowało 388 tys. $\mathrm{km}^{2}$ i było dwukrotnie mniejsze od Pierwszej Rzeczypospolitej, ale jednak dwukrotnie większe od tego, które proponował Jankowski. Trwało w tych granicach zaledwie 20 lat. Po drugiej wojnie światowej nastąpił powrót do wizji Jankowskiego, ale nowe granice narzucone $\mathrm{w}$ rezultacie decyzji poczdamskich były o wiele bardziej korzystne. Polska ukształtowana w granicach między linią Curzona na wschodzie, a linią Odry i Nysy Łużyckiej na zachodzie jest znacznie większa od tej, którą proponował. Została znacznie przesunięta na zachód, uzyskując szeroki dostęp do morza. $\mathrm{Na}$ pograniczu wschodnim i północnym także ma granice znacznie korzystniejsze niż te, które zarysował Jankowski. Tu jednak różnice są niewielkie.

Obie wizje w pewnym stopniu uległy urzeczywistnieniu po 1945 r. Odrodziła się Polska, po wielkich przesiedleniach jako państwo jednolite narodowościowo, W tym sensie Jankowski trafnie przewidział przyszłość. Nie mógł wówczas zakładać, że polski obszar etniczny powiększy się o jedną trzecią, a granica dojdzie do linii Odry i Nysy Łużyckiej. Paradoksalnie, zgodnie z koncepcją Żebrowskiego nowa Polska po drugiej wojnie światowej mocno nawiązywała do odległej historii. Zamiast wielkiej Polski Jagiellońskiej powstała Polska Piastowska o granicach zbliżonych do tych, jakie miała w 1136 r. za panowania Bolesława Krzywoustego.

Dzięki porównaniu terytorium państwa polskiego $\mathrm{w}$ jego realnie istniejących konfiguracjach granicznych z okresu międzywojennego i po drugiej wojnie światowej oraz dwóch załączonych tutaj map, będących wytworem myśli dwóch badaczy, pojawiła się możliwość zastanowienia się nad przemianami geopolitycznymi, jakie 
miały miejsce w ciagu ostatnich stu lat na ziemiach polskich. W rezultacie skomplikowanych i nieoczekiwanych zarówno przez Żebrowskiego, jak i Jankowskiego perturbacji politycznych, nie było szans na powstanie Rzeczypospolitej rozciągającej się aż po Dniepr i Dźwinę. Powstanie jednak niepodległej Ukrainy, Białorusi, Litwy i Łotwy odsunęło Rosję na wschód i zmieniło charakter polskiej granicy wschodniej, co przyświecało dążeniom Żebrowskiego. Scenariusz terytorialny oczekiwany przez Jankowskiego również nie został spełniony ani w wyniku pierwszej, ani drugiej wojny światowej. Nie istnieje na mapie Europy mała, szczątkowa Polska, która była według niego jedyną realną możliwością spełnienia oczekiwań Polaków. Uformowała się po kataklizmie drugiej wojny światowej nowa poczdamska Polska o zwartym i dogodnym terytorium, przesunięta znacznie na zachód. Dzięki selektywnym, przymusowym migracjom stała się państwem jednolitym narodowościowo, w którym nie tylko Gdańsk, ale i Wrocław, i Szczecin stały się miastami etnicznie polskimi. Pomimo że w sensie terytorialnym obie koncepcje nie zostały urzeczywistnione, to ich wymowa ideowa była obecna w świadomości Polaków żyjących w XX w. i determinowała ich działania polityczne.

\section{Bibliografia}

Bujak F., Oskar Żebrowski i jego pogląd na dzieje Polski, Kraków 1936.

Eberhardt P., Polska i jej granice. Z historii polskiej geografii politycznej, Lublin 2004.

Jankowski Cz., Polska etnograficzna, Warszawa 1914.

Romer E., Przyrodzone podstawy Polski historycznej, Lwów 1912.

Sykulski L., Oskar Żebrowski - prekursor geopolityki polskiej, „Przegląd Geopolityczny”, 2, 2010, s. 169-174.
Wapiński R., Polska i mate ojczyzny Polaków. Z dziejów ksztattowania się świadomości narodowej w XIX $i$ XX wieku po wybuch II wojny światowej, Wrocław 1994.

Wysłouch B., Szkice programowe, „Przegląd Społeczny”, (6), 1886, s. 395-493.

Żebrowski O., Polska. Ogólny zarys przyczyn wzrostu $i$ upadku dawnego państwa polskiego, Paryż 1847.

\section{From historical to ethnic Poland (from Oskar Żebrowski's vision to Czesław Jankowski's project)}

\section{Summary}

The article presents two past territorial concepts of the hypothetical political borders of Poland. The first was created in 1847 by Oskar Żebrowski. The second one was developed by Czesław Jankowski and published in 1914. Both authors presented their original ideas about the hypothetical future borders of Poland, and the concepts were presented as maps and then described and interpreted. The first author, Oskar Żebrowski, mapped out the theoretical borders of future Poland basing on the historical rationales relating to the Polish-Lithuanian Commonwealth.
The second author, Czesław Jankowski, preferred ethnic rationales. He tried to map out the borders of future Poland based on the distribution of people declaring Polish nationality and speaking the Polish language. As a result of different assumptions, Poland's territories differed significantly by size and spatial layout. The study of both maps and the comparison with the future political situation after World War I and World War II allow the evaluation of both visions' geographical accuracy. 
prof. dr hab. Piotr Eberhardt (zm. 2020) - pracownik Zakładu Przestrzennego Zagospodarowania w Instytucie Geografii i Przestrzennego Zagospodarowania Polskiej Akademii Nauk, przewodniczący Rady Naukowej Instytutu Geopolityki

Prof. Piotr Eberhardt (d. 2020) - employee of the Department of Spatial Organisation at the Institute of Geography and Spatial Organisation of the Polish Academy of Sciences, chairman of the Scientific Council of the Institute of Geopolitics 